
\title{
25 Research Soure \\ Effects of Irrigation Techniques on Yield, Quality and Water Use Efficiency of Greenhouse Grown Celery (Apium graveolens L.)
}

Shenglin Wang

China Agricultural University https://orcid.org/0000-0003-2545-1222

Chen Luo

China Agricultural University

Yue Xie

China Agricultural University

Xiaotang Jiang

China Agricultural University

Yixin Wang

China Agricultural University

Qian Wang ( $\nabla$ wangq@cau.edu.cn )

Research article

Keywords: celery, irrigation, quality, yield, water use efficiency

Posted Date: June 22nd, 2020

DOI: https://doi.org/10.21203/rs.3.rs-32623/v1

License: (c) (i) This work is licensed under a Creative Commons Attribution 4.0 International License.

Read Full License 


\section{Abstract}

Background: Traditional irrigation methods in protected vegetable production such as furrow irrigation result in low water use efficiency. New techniques, such as drip irrigation, micro-sprinkling irrigation have been developed for improving water use efficiency. However, these techniques have not been tested in greenhouse celery production. In this study, three different irrigation techniques micro-sprinkler irrigation (MS), furrow irrigation under plastic film mulching (PF) and micro-sprinkler irrigation under the plastic film mulching (MSP) were investigated whether the three techniques can improve the yield, quality and water use efficiency of greenhouse-grown celery, compared to furrow irrigation (FI).

Results: The individual plant weight of celery was higher under MS, PF and MSP than under FI in both autumn season crop (AC) and spring season crop (SC), compared to FI. In AC and SC, the economic yield of celery increases under MSP by $54.18 \%$ and $49.55 \%$, the economic yield of celery increases under PF by $30.37 \%$ and $34.10 \%$. The irrigation amount of MSP was 151.69 and $179.91 \mathrm{~m}^{3} 667 \mathrm{~m}^{-2}$ in AC and SC, which was $23.13 \%$ and $27.27 \%$ lower than that of FI. The irrigation amount of PF was 151.69 and 196.78 $\mathrm{m}^{3} 667 \mathrm{~m}^{-2}$ in AC and SC, which was $23.13 \%$ and $20.45 \%$ lower than that of FI. PF and MSP reduced the irrigation amount of celery cultivation in greenhouse, and soil evaporation content.

Conclusions: In short, MSP and PF promoted the growth and yield of celery in greenhouse with improved quality and water use efficiency.

\section{Background}

In China, the area of facility cultivation is increasing, especially in horticultural production ${ }^{[1]}$. Sufficient irrigation guarantees crop yields. However, some outdated techniques, such as diffuse irrigation and furrow irrigation are still used for facility cultivation in China, resulting in low water use efficiency. There is a need for the development of new irrigation techniques for water saving ${ }^{[2]}$. Nowadays, several irrigation techniques have been verified to decrease the irrigation amount without hampering yields. For example, micro-spray irrigation results in the increase of tomato yield $27 \%$ and water saving $21 \%$ by improving the root growth with improved air humidity and microclimate ${ }^{[3]}$. The micro-tube, drip and micro-sprinkler irrigation improve the mean head weight, mean head diameter and plant height of cabbage and reduce irrigation water for cabbage by $61.44 \%, 59.28 \%$ and $36.82 \%$ respectively, compared to surface furrow irrigation due to it had better retention of soil moisture without drought or excess water supply ${ }^{[4]}$. Subsurface drip irrigation improved nutrient uptakes by onion roots, leading to the highest onion yield, compared to surface furrow irrigation ${ }^{[5]}$. Sufficient irrigation maintains the crop yield, while it had a negative effect on the fruit quality ${ }^{[6]}$. For example, the content of soluble sugar and organic acid decreased with the increase of irrigation amount in muskmelon ${ }^{[7]}$ and watermelon ${ }^{[8]}$.

Apart from using advanced irrigation techniques, mulching applications can effectively modify the hydrothermal conditions in micro-environment for plant growth. Plastic film mulching may reduce ineffective evaporation by reducing surface air flow ${ }^{[9]}$, increase soil temperature and improve soil 
physical properties by reducing wind-candles and keeping the soil loose ${ }^{[10]}$. Moreover, it can inhibit weeds by reducing the light intensity beneath the plastic film and decrease the occurrence of diseases and insect pests due to its reflective properties ${ }^{[11,12]}$. With such benefits, plastic film mulching promotes the growth of wheat and maize, resulting in improved crop yield and water use efficiency ${ }^{[13,14]}$. Sub-film micro-spraying, where the micro-spraying is implemented under plastic film mulching, increases water use efficiency in lettuce compared to traditional irrigation method like furrow irrigation ${ }^{[15]}$. Meanwhile, plastic film mulching can further reduce the soil water evaporation directly in the vertical direction ${ }^{[16]}$. Both black polyethylene mulch and wheat straw mulch improved the fruit yield, fruit size, dry matter, total leaf area, and nutrient concentrations in leaves of cucumber ${ }^{[17]}$.

Water demands of crops refers to the sum of crop transpiration, crop water content and ground evaporation between plants under appropriate water conditions. Therefore, water demands of crop depend on environmental factors such as temperature ${ }^{[18]}$, and it varies during the different growing stages. The intensity and duration of water stress had effects on crop growth. Water deficit slow the growth and development of plants and reduce the leaf area of pepper ${ }^{[19]}$. The pepper yield decreased by $4.5 \%$ when the irrigation amount was $75 \%$ of the total irrigation amount ${ }^{[22]}$. Therefore, it is critical to optimize the allocation of irrigation water resources, which directly reflects in the amount of crop water demand ${ }^{[20,21]}$.

Celery (Apium graveolens L.) is a chimonophilous, biennial crop of the Umbelliferae, rich in vitamins, dietary fiber and minerals ${ }^{[23]}$. It is sensitive to changes in soil moisture ${ }^{[24]}$. The soil moisture has a great influence on its growth, development, yield and quality ${ }^{[25]}$. The purpose of this study is to investigate whether irrigation techniques such as spray irrigation can improve the yield, quality and water use efficiency of greenhouse grown celery in spring and autumn season, by celery growth, water allocation and nutrient contents.

\section{Results}

\section{Effects of water irrigation techniques on WUE}

The $\mathrm{WUE}_{\mathrm{e}}$ and $\mathrm{WUE}_{\mathrm{b}}$ were affected statistically significant from irrigation techniques $(p<0.05)$ in both AC and $\mathrm{SC}$. $\mathrm{WUE}_{\mathrm{e}}$, and $\mathrm{WUE}_{\mathrm{b}}$ were all significantly higher than of the control $(\mathrm{FI})$, indicating that the irrigation techniques improved WUE, and the MSP treatment had highest WUE. In AC (Fig. 2), the WUE in MS, PF and MSP treatments were significantly higher than that of the control $(\mathrm{FI})$, of which were $30.06 \%, 74.47 \%$ and $94.57 \%$, respectively. The $\mathrm{WUE}_{\mathrm{b}}$ were significantly higher than that of the control $(\mathrm{FI})$, of which were $28.74 \%, 72.79 \%$ and $92.99 \%$, respectively. In SC (Fig. 3), the WUE $_{e}$ in MS, PF and MSP treatments were significantly higher than that of the control $(\mathrm{FI})$, of which were $30.15 \%, 58.12 \%$ and $89.01 \%$, respectively. The $\mathrm{WUE}_{\mathrm{b}}$ were significantly higher than that of the control (FI), of which were $29.05 \%, 58.18 \%$ and $86.77 \%$, respectively.

\section{Effects of water irrigation techniques on plant growth}


In AC, there was no significant difference in plant height between different treatments until the peak growth stage of leaf cluster (35 days after transplanting, from September 4, 2015 to November 11, 2015) (Fig. 4). The celery heights in PF and MSP started to be higher than those in FI and MS from August 30, 2015 to the harvest time $(p<0.05))$. In SC, there was no significant difference in plant height between different treatments until the peak growth stage of leaf cluster (40 days after planting, from April 12, 2016 to May 31, 2016) (Fig. 4). The celery heights on April 12 and May 1, 2016 was higher in PF and MSP than that in $\mathrm{FI}(p<0.05)$. The celery heights in PF and MSP started to be higher than those in $\mathrm{FI}$ and MS from April 12, 2016 to the harvest time $(p<0.05))$.

In AC, the dry weights of the whole plant was lowest in $\mathrm{Fl}$, the order of whole plant weights was MSP > PF $>\mathrm{MS}>\mathrm{Fl}$, with significant difference $(p<0.05)$ between treatments and control $(\mathrm{Fl})$ (Table 3$)$. The aboveground dry weights was lowest in $\mathrm{Fl}$, the order of aboveground dry weights was $\mathrm{MSP}>\mathrm{PF}>\mathrm{MS}>\mathrm{Fl}$, with significant difference $(p<0.05)$ between treatments and control $(\mathrm{FI})$ (Table 3$)$. The underground dry weight was lower in FI than, those in MSP,PF and MS $(p<0.05)$ (Table 3). Under different irrigation methods, the root-shoot ratio (R/S) of PF and MSP was larger than that of FI $(p<0.05)$ (Table 3). In SC, the dry weights of the whole plant was lowest in $\mathrm{Fl}$, the order of whole plant weights was $\mathrm{PF}>\mathrm{MSP}>\mathrm{MS}$ $>\mathrm{Fl}$, with significant difference $(p<0.05)$ between treatments and control $(\mathrm{FI})($ Table 3$)$. The aboveground dry weights was lowest in $\mathrm{Fl}$, the order of aboveground dry weights was MSP $>\mathrm{PF}>\mathrm{MS}>\mathrm{Fl}$, with significant difference $(p<0.05)$ between treatments and control $(\mathrm{FI})$ (Table 3$)$. The underground dry weight was lower in FI than, those in MSP,PF and MS $(p<0.05)$ (Table 3). Under different irrigation methods, the R/S of MS, PF and MSP was lower than that of FI $(p<0.05)$ (Table 3$)$.

Table 3

Effects of irrigation techniques for the individual plant weight

\begin{tabular}{|c|c|c|c|c|c|}
\hline period & treatment & $\begin{array}{l}\text { dry weights of } \\
\text { whole plant (g) }\end{array}$ & $\begin{array}{l}\text { dry weights of } \\
\text { aboveground (g) }\end{array}$ & $\begin{array}{l}\text { dry weights of } \\
\text { underground (g) }\end{array}$ & $\begin{array}{l}\text { R/S } \\
\text { (dry) }\end{array}$ \\
\hline \multirow[t]{4}{*}{$A C$} & $\mathrm{FI}$ & $25.95 c \pm 2.7$ & $24.32 c \pm 0.6$ & $1.63 a \pm 0.5$ & $0.067 \mathrm{c}$ \\
\hline & MS & $26.59 c \pm 2.1$ & $24.92 c \pm 2.7$ & $1.67 a \pm 0.4$ & $0.067 c$ \\
\hline & PF & $33.83 b \pm 1.2$ & $31.13 b \pm 2.5$ & $2.70 \mathrm{a} \pm 0.5$ & $0.087 \mathrm{~b}$ \\
\hline & MSP & $40.01 a \pm 2.3$ & $36.96 a \pm 2.5$ & $3.05 a \pm 0.7$ & $0.083 a$ \\
\hline \multirow[t]{4}{*}{ SC } & $\mathrm{FI}$ & $27.23 b \pm 2.9$ & $24.60 c \pm 2.4$ & $2.63 a \pm 0.6$ & $0.107 \mathrm{c}$ \\
\hline & MS & $32.03 a b \pm 3.9$ & $29.33 b \pm 2.6$ & $2.70 a \pm 0.8$ & $0.092 b$ \\
\hline & PF & $36.92 \mathrm{a} \pm 3.4$ & $33.62 a \pm 0.7$ & $3.30 \mathrm{a} \pm 0.7$ & $0.098 a$ \\
\hline & MSP & $36.70 a \pm 0.3$ & $33.80 a \pm 1.6$ & $2.90 \mathrm{a} \pm 0.6$ & $0.086 a$ \\
\hline
\end{tabular}


The premise of selecting irrigation method is to ensure the yield and quality of plants, and economic output is the main indicator to measure the yield and economic benefit of celery. In AC, the EY was lowest in $\mathrm{Fl}$, compared to MS, PF and MSP by $20.01 \%, 34.10 \%$ and $49.55 \%$, respectively $(p<0.05)$, the BY was lowest in $\mathrm{Fl}$, compared to MS, PF and MSP by $18.81 \%, 32.83 \%$ and $48.34 \%$, respectively $(p<0.05)$ (Fig. 5 ). In SC, the EY was lowest in $\mathrm{FI}$, compared to MS, PF and MSP by $21.31 \%, 25.79 \%$ and $37.49 \%$, respectively $(p<0.05)$, the BY was lowest in $\mathrm{Fl}$, compared to MS, PF and MSP by $20.26 \%, 25.83 \%$ and $35.81 \%$, respectively $(p<0.05)$ (Fig. 5).

\section{Effects of water irrigation techniques on celery root system}

The RL, RSA, and RV were affected statistically significant from irrigation techniques $(p<0.05)$ in both AC and SC. In AC, the RL of MS, PF, MSP were $20.26 \%, 33.31 \%$ and $45.45 \%$ higher than that of control (FI), respectively, the RSA was $2.83 \%, 0.70 \%$ and $18.34 \%$ higher than that of control $(\mathrm{FI})$, respectively, the RV was $11.14 \%, 32.27 \%, 34.77 \%$ higher than that of control (FI), respectively (Table 4). In SC, the RL of MS, PF, MSP were $5.90 \%, 34.18 \%$ and $49.03 \%$ higher than that of control (FI), respectively, the RSA was $3.40 \%, 50.42 \%$ and $60.49 \%$ higher than that of control $(\mathrm{FI})$, respectively, the RV was $14.58 \%, 17.59 \%$ and $97.45 \%$ higher than that of control (FI), respectively (Table 4$)$.

Table 4

Effects of different irrigation techniques on root system:

\begin{tabular}{|c|c|c|c|c|}
\hline period & treatment & $\mathrm{RL}(\mathrm{cm})$ & $\mathrm{RSA}\left(\mathrm{cm}^{2}\right)$ & $\mathrm{RV}\left(\mathrm{cm}^{3}\right)$ \\
\hline \multirow[t]{4}{*}{$A C$} & $\mathrm{FI}$ & $936.22 c \pm 37.3$ & $234 b \pm 8.4$ & $4.4 b \pm 0.1$ \\
\hline & MS & $1125.92 b \pm 13.1$ & $240.63 a b \pm 13.2$ & $4.89 b \pm 0.1$ \\
\hline & PF & $1248.03 a \pm 48.7$ & $235.64 b \pm 16.2$ & $5.82 a \pm 0.4$ \\
\hline & MSP & $1361.7 a \pm 38$ & $276.91 a \pm 9.6$ & $5.93 a \pm 0.1$ \\
\hline \multirow[t]{4}{*}{$\mathrm{SC}$} & $\mathrm{FI}$ & $750.77 b \pm 47$ & $214.97 b \pm 8.9$ & $4.32 b \pm 0.3$ \\
\hline & MS & $795.08 b \pm 18.9$ & $207.66 b \pm 7.6$ & $4.95 b \pm 0.4$ \\
\hline & $\mathrm{PF}$ & $1007.42 \mathrm{a} \pm 6.4$ & $323.36 a \pm 10.3$ & $5.08 b \pm 0.3$ \\
\hline & MSP & $1118.86 a \pm 57.5$ & $345.01 a \pm 10.2$ & $8.53 a \pm 0.1$ \\
\hline
\end{tabular}

\section{Effects of water irrigation techniques on soluble sugar, vitamin $C$ and fiber contents of celery}

The contents of soluble sugar and vitamin $\mathrm{C}$ in the celery were highest in MSP, followed by MS and PF, and was lowest in FI in both AC and SC, while the contents were increased to different extents in two growing seasons. The soluble sugar contents were $44.64 \%, 106.96 \%$ and $141.74 \%$ higher in MS, PF and 
MSP treatments respectively than that in the control ( $\mathrm{FI}$ ) in AC (Table 5), and $4.19 \%, 33.26 \%$ and $59.69 \%$ higher in SC (Table 5).

Table 5

The effects of different irrigation techniques on the quality of celery

\begin{tabular}{|c|c|c|c|c|c|c|c|}
\hline \multirow[t]{3}{*}{ period } & \multirow[t]{3}{*}{ treatment } & \multirow{3}{*}{$\begin{array}{l}\text { soluble } \\
\text { sugar } \\
(\%)\end{array}$} & \multirow{3}{*}{$\begin{array}{l}\text { vitamin } \\
\mathrm{C} \\
(\mathrm{mg} \mathrm{kg} \\
\begin{array}{l}1 \\
\text { ) }\end{array}\end{array}$} & \multicolumn{4}{|c|}{ fiber content (\%) } \\
\hline & & & & \multicolumn{2}{|c|}{ outer petiole } & \multicolumn{2}{|c|}{ inner petiole } \\
\hline & & & & cellulose & hemicellulose & cellulose & hemicellulose \\
\hline \multirow[t]{4}{*}{$\mathrm{AC}$} & $\mathrm{FI}$ & $\begin{array}{l}3.45 c \pm \\
1.0\end{array}$ & $\begin{array}{l}85.97 \mathrm{c} \pm \\
6.7\end{array}$ & $\begin{array}{l}16.39 a \\
\pm 0.6\end{array}$ & $6.44 a \pm 1.0$ & $\begin{array}{l}\text { 12.99ab } \\
\pm 0.9\end{array}$ & $5.55 a \pm 0.8$ \\
\hline & MS & $\begin{array}{l}4.99 b \pm \\
0.3\end{array}$ & $\begin{array}{l}89.28 \mathrm{c} \pm \\
3.3\end{array}$ & $\begin{array}{l}16.36 a \\
\pm 1.7\end{array}$ & $5.91 a \pm 1.7$ & $\begin{array}{l}13.94 a \\
\pm 0.7\end{array}$ & $4.97 a b \pm 0.9$ \\
\hline & PF & $\begin{array}{l}7.14 a \pm \\
0.8\end{array}$ & $\begin{array}{l}109.12 \mathrm{~b} \\
\pm 5.0\end{array}$ & $\begin{array}{l}16.01 a \\
\pm 0.4\end{array}$ & $5.71 a \pm 0.7$ & $\begin{array}{l}12.48 \mathrm{~b} \\
\pm 0.7\end{array}$ & $4.49 a b \pm 0.9$ \\
\hline & MSP & $\begin{array}{l}8.34 a \pm \\
0.6\end{array}$ & $\begin{array}{l}128.96 a \\
\pm 6.1\end{array}$ & $\begin{array}{l}14.69 a \\
\pm 0.6\end{array}$ & $5.70 a \pm 1.4$ & $\begin{array}{l}12.35 \mathrm{~b} \\
\pm 0.5\end{array}$ & $3.87 b \pm 0.6$ \\
\hline \multirow[t]{4}{*}{ SC } & $\mathrm{FI}$ & $\begin{array}{l}4.54 c \pm \\
0.9\end{array}$ & $\begin{array}{l}88.62 \mathrm{~d} \\
\pm 4.5\end{array}$ & $\begin{array}{l}14.68 \mathrm{a} \\
\pm 1.2\end{array}$ & $7.53 a \pm 1.3$ & $\begin{array}{l}13.13 a \\
\pm 1.1\end{array}$ & $7.82 a \pm 0.4$ \\
\hline & MS & $\begin{array}{l}4.73 c \pm \\
0.5\end{array}$ & $\begin{array}{l}110.75 \mathrm{c} \\
\pm 7.8\end{array}$ & $\begin{array}{l}14.74 a \\
\pm 1.2\end{array}$ & $7.21 a \pm 1.5$ & $\begin{array}{l}12.55 a \\
\pm 1.7\end{array}$ & $7.45 a \pm 1.9$ \\
\hline & PF & $\begin{array}{l}6.05 b \pm \\
0.6\end{array}$ & $\begin{array}{l}140.85 b \\
\pm 8.7\end{array}$ & $\begin{array}{l}14.49 a \\
\pm 1.1\end{array}$ & $5.76 a \pm 1.2$ & $\begin{array}{l}12.34 a \\
\pm 1.1\end{array}$ & $5.91 a \pm 1.8$ \\
\hline & MSP & $\begin{array}{l}7.25 a \pm \\
0.3\end{array}$ & $\begin{array}{l}159.00 \mathrm{a} \\
\pm 3.4\end{array}$ & $\begin{array}{l}11.79 \mathrm{~b} \\
\pm 1.5\end{array}$ & $5.43 a \pm 1.5$ & $\begin{array}{l}11.72 \mathrm{a} \\
\pm 1.4\end{array}$ & $5.13 a \pm 1.6$ \\
\hline
\end{tabular}

The vitamin C contents were $3.85 \%, 26.93 \%$, and $50.01 \%$ higher in MS, PF and MSP treatments respectively than that in the control (FI) in AC (Table 5), and $24.97 \%, 58.94 \%$, and $79.42 \%$ higher in SC (Table 5).

The total fiber contents of celery in different treatments was not significantly different in both seasons. However, the hemicellulose contents of the inner petiole were lower in MSP than that in $\mathrm{FI}(p<0.05)$ in AC (Table 5). The hemicellulose contents in the outer petiole were $8.23 \%, 11.34 \%$, and $11.49 \%$ lower in MS, PF and MSP treatments respectively than that of the control (FI) in AC (Table 5), and $4.25 \%, 23.51 \%$ and $27.89 \%$ lower in SC (Table 5). The hemicellulose contents of the inner petiole were $10.45 \%, 19.10 \%$ and $30.27 \%$ lower in MS, PF and MSP treatments respectively than that of the control (FI) in AC (Table 5), $4.73 \%, 24.42 \%$ and $34.40 \%$ lower in SC (Table 5).

\section{Discussion}


This study mainly investigated the effects of plastic film mulching and micro-sprinkling irrigation techniques on the WUE, growth, quality, total yield and water distribution of celery in greenhouse of AC and SC. It was found that plastic film mulching and micro-sprinkling irrigation could improve WUE (Fig. 2, 3) and promote the growth (Fig. 4) of celery. In addition, these techniques improved the quality (Table 5) and promote root growth of celery (Table 4).

Micro-sprinkler and plastic film mulching accelerated celery growth (Table 3), which showed transverse thickening and longitudinal growth. Previous study showed that film mulching significantly increased onion yield, compared to bare soil. Irrigation water is also reduced by the presence of mulch covers ${ }^{[26]}$. In both $\mathrm{AC}$ and $\mathrm{SC}$, the plant height of the two treatments covered with plastic film was higher than that of the other two treatments $(p<0.05)$ in harvest. This increased height could be ascribed to increased soil temperature and soil moisture content with full film mulching. With full film mulching, soil temperature and soil moisture content increased more than those under partial film mulching ${ }^{[9]}$. The plastic film mulching can improve soil properties and increase crop yield ${ }^{[27,28]}$. Similarly, the irrigation techniques improved the yield of celery and WUE. the MSP and PF had high total yield and WUE due to it has better root system (Table 4) both in AC and SC, the roots absorbed more nutrients and substances. In addition, plastic film mulching can reduces soil moisture evaporation, improving WUE. Previous research has indicated that the combined plastic film mulching-micro-sprinkler irrigation was the most suitable irrigation approach for increasing lettuce yield and it had best WUE ${ }^{[15]}$.

The quality of celery was better when covered with plastic film than that uncovered by plastic film, MSP and PF had higher plant height and individual weight, this was probably due to it had higher transpiration content, which had improvement of the water and mineral nutrients transported in celery (Table 5) and tomato ${ }^{[29]}$. Plastic film mulching can improve soil quality ${ }^{[30]}$ and prevent water evaporation ${ }^{[31]}$, which were beneficial to accumulation of plant biomass (Table 3). This study shows that PF and MSP have obviously improved the celery's soluble sugar, vitamin C, reduce the content of cellulose, hemicellulose contents (Table 5), related to the promotion on the growth of the root and the absorption of nutrients. These promotions under the plastic film mulching and micro-sprinkling have been ascribed to the increase of soil temperature and decrease of the soil bulk density ${ }^{[32]}$. Root water absorption capacity is the key factor determining the balance of transpiration and plant water status, while root growth and distribution are closely related to soil moisture and nutrient status ${ }^{[33]}$. In this study, MSP and PF had better root system, it had promote the growth and improve quality of celery.

\section{Conclusions}

Micro-sprinkler and plastic film covering can increase root growth. Meanwhile, it promoted the growth of celery in both aboveground and underground parts, improved the quality of celery in both AC and SC, increased the total yield and WUE of celery. All in all, in this study, it is considered that MSP and PF treatment is the best treatment under the conditions of this experiment, it promotes celery growth, improves quality, and is most effective in increasing yield and water use efficiency. 


\section{Methods}

\section{Field sites and experimental design}

The experiment was conducted in the greenhouse at the Experimental Station, China Agricultural University, Beijing $\left(39^{\circ} 54 N^{\prime}, 116^{\circ} 23 E^{\prime}\right)$, China, during June 2015 to October 2016 . The experiment design was complete random block design with three replicates. Four irrigation treatments were furrow irrigation (FI), micro-sprinkler irrigation (MS), furrow irrigation under plastic film mulching (PF) and micro-sprinkler irrigation under the plastic film mulching (MSP) (Fig. 1). Moisture transducer (Shengshixintong Technology, Beijing, China) was used to monitor soil moisture. The irrigation started when soil moisture lowered to $60 \%$ of field capacity, and the total irrigation in four treatments are shown in Table 1 . The irrigation water given each time was assumed to increase the soil moisture to $80 \%$ of field capacity. Thus, the irrigation amount for each time was $15.21 \mathrm{~m}^{3} 667 \mathrm{~m}^{-2}$ in AC and $16.87 \mathrm{~m}^{3} 667 \mathrm{~m}^{-2}$ in SC, calculated with the following formula ${ }^{[15]}$.

Table 1

Total irrigation in four treatments

\begin{tabular}{|lll|}
\hline treatment & $\begin{array}{l}\text { AC } \\
\left(\mathrm{m}^{3} 667 \mathrm{~m}^{-2}\right)\end{array}$ & $\begin{array}{l}\text { SC } \\
\left(\mathrm{m}^{3} 667 \mathrm{~m}^{-2}\right)\end{array}$ \\
\hline $\mathrm{FI}$ & 197.33 & 247.37 \\
\hline $\mathrm{MS}$ & 182.12 & 230.51 \\
\hline $\mathrm{PF}$ & 151.69 & 196.78 \\
\hline $\mathrm{MSP}$ & 151.69 & 179.91 \\
\hline Note: AC: Autumn season crop, SC: Spring season crop. \\
\hline
\end{tabular}

$I=r \times p \times h \times \theta_{f} \times s \times\left(q_{1}-q_{2}\right) / \eta,(1)$

where $r$ is the soil bulk density $\left(\mathrm{g} \mathrm{cm}^{-3}\right), \mathrm{p}$ is the soil wetting ratio with a value of $100 \%, \mathrm{~h}$ is the planned wetting layer $(0.3 \mathrm{~m}), \theta_{\mathrm{f}}$ is the field capacity $(\%), q_{1}$ and $q_{2}$ are $80 \%, 60 \%$, respectively, $s$ is the area of $667 \mathrm{~m}^{2}, \eta$ is the water use coefficient, taken as a value of 1 in this experiment.

The celery (variety 'Ventura') was germinated in greenhouse use 128-plug tray (one plug with one seed) with vegetable seedling substrate (charcoal, vermiculite, slag and perlite are mixed by volume ratio 20: 20 : 50: 10) on June 15, 2015 for AC and on January 20, 2016 for SC. The four-leaf seedlings with similar morphological were transplanted on August 1, 2015 for AC and on March 2, 2016 for SC in a plot with size of $3.6 \mathrm{~m}^{2}$ (3.60 m in length $\times 1.0 \mathrm{~m}$ in width), which consisted of four rows with a $20 \mathrm{~cm} \times 25 \mathrm{~cm}$ row space in each furrow (Fig. 1). Plastic film inserted vertically $50 \mathrm{~cm}$ into the soil profile between adjacent

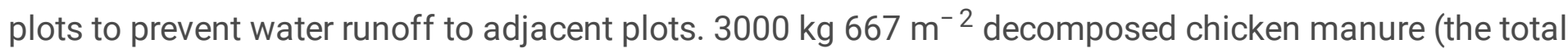
content of $N, P$ and $K \geq 4 \%$, total organic matter content $\geq 30 \%$ ) and $150 \mathrm{~kg}$ compound fertilizer $667 \mathrm{~m}^{-2}$ 
(the contents of $\mathrm{N}, \mathrm{P}_{2} \mathrm{O}_{5}, \mathrm{~K}_{2} \mathrm{O}$ were $15 \%, 10 \%$ and $15 \%$ respectively) were applied before planting. The celery was harvested on November 11, 2015 and on May 31, 2016. The detailed soil physical and chemical characteristics are shown in Table 2.

Table 2

Soil physical and chemical properties in the greenhouse.

\begin{tabular}{|c|c|c|c|c|c|c|c|}
\hline & $\begin{array}{l}\text { organic } \\
\text { matter } \\
(\%)\end{array}$ & $\begin{array}{l}\text { total N } \\
\left(g_{\text { kg }}^{-}\right. \\
\left.{ }^{1}\right)\end{array}$ & $\begin{array}{l}\text { available } N \\
\left(\mathrm{mg} \mathrm{kg}^{-1}\right)\end{array}$ & $\begin{array}{l}\text { available P } \\
\left(\mathrm{mg} \mathrm{kg}^{-1}\right)\end{array}$ & $\begin{array}{l}\text { available K } \\
\left(\mathrm{mg} \mathrm{kg}^{-1}\right)\end{array}$ & $\begin{array}{l}\text { bulk } \\
\text { density ( } \mathrm{g} \\
\left.\mathrm{cm}^{-3}\right)\end{array}$ & $\begin{array}{l}\text { field capacity } \\
\left(\mathrm{cm}^{3} \mathrm{~cm}^{-3}\right)\end{array}$ \\
\hline$A C$ & 2.47 & 1.66 & 228.75 & 101.46 & 260.96 & 1.21 & 31.43 \\
\hline SC & 2.39 & 1.48 & 206.32 & 78.89 & 240.33 & 1.12 & 37.63 \\
\hline
\end{tabular}

\section{Micro-spraying irrigation technique}

In the treatments with micro-spraying irrigation technique, main rigid pipes were with a diameter of 50 $\mathrm{mm}$ and micro-sprinkler pipes were with a diameter of $28.6 \mathrm{~mm}$, a hole with $0.1 \mathrm{~mm}$ diameter (Figure ). In the MSP treatment, the same pipes were used as in the MS treatment and placed under the plastic film. The plastic film used in PF and MSP treatments was an ordinary black agricultural plastic film with a thickness of $0.01 \mathrm{~mm}$ (Figure 1).

\section{The soil and plant sampling and analysis}

Soil samples were taken by soil-drilling from $0-10,10-20$ and $20-30 \mathrm{~cm}$ soil layers before planting (July 30, 2015 for AC and on March 1, 2016 for SC), during the growing season (September 16, 2015 for AC and on April 12, 2016 for SC) and after harvest (November 10, 2015 for AC and on May 30, 2016 for SC). Five soil cores on raised bed were taken in each plot using the soil-drilling in an S-shape. Soil was thoroughly mixed, and about $1 \mathrm{~kg}$ of soil was sieved through a $1-\mathrm{mm}$ mesh and afterwards air-dried ${ }^{[34,35]}$.

Plant samples were collected using the five-spot method. Plant height (from ground to the highest point of plant) was measured by ruler (accuracy is $1 \mathrm{~mm}$ ). Ten individual plants were randomly selected for each plot to determine the plant height every 10 days (from August 10, 2015 to October 29, 2015 in AC, and from March 3, 2016 to May 21, 2016). At harvest (November 10, 2015 for AC and on May 30, 2016 for SC), ten plants for each plot were sampled both aboveground and belowground for plant weight. The fresh weight was measured using electronic balance ALC-210.2 (Puyi Electronic Technology, Shanghai, China). The plant samples were oven-dried at $105^{\circ} \mathrm{C}$ for $30 \mathrm{~min}$ and then at $80^{\circ} \mathrm{C}$ for 36 hours to constant weight.

The soluble sugar contents were analyzed by anthrone colorimetry method ${ }^{[37]} .0 .5 \mathrm{~g}$ of fresh celery leaves were cut into pieces and put into a test tube, to which $5 \mathrm{~mL}$ distilled water was added and mixed. After $30 \mathrm{~min}$ in a boiling water bath, the supernatant was collected, this step was repeated twice. Extra distilled water was added to fill the solution to $10 \mathrm{~mL}$, then analyzed with a spectrophotometer UV-2102C (Honglang Company, ZhengZhou, China) at $630 \mathrm{~nm}$ wavelengths. 
For determination of vitamin $\mathrm{C}^{[38]}, 10 \mathrm{~g}$ fresh celery leaves were grinded $60 \mathrm{~mL}$ of mixture of metaphosphoric and acetic acid $\left(3 \% \mathrm{HPO}_{3}+8 \% \mathrm{CH}_{3} \mathrm{COOH}\right)$ was added instantly to avoid vitamin $\mathrm{C}$ breakdown in air. The dilutions were shaken in shaker reciprocating 190-200 rpm min-1 for one hour using. After that, $2 \mathrm{~mL}$ of starch indicator was added to it and the solution was immediately titrated with standard solution of iodine $\mathrm{I}_{2}$ until the solution turns the color from initial reddish-brown color to greyishblue.

Fiber content was measured by ANKOM A200i semi-automatic fiber analyzer ${ }^{[39]}: 0.5 \mathrm{~g}$ of petiole dry sample was put into the filter bag. The filter bag was washed with the configured neutral detergent solution in the ANKOM A200i semi-automatic fiber analyzer (ANKOM Technology, New York, America) for $75 \mathrm{~min}$. The filter bag was taken out and rinsed with acetone for $5 \mathrm{~min}$. After being dried naturally, it was put into the oven at $100^{\circ} \mathrm{C}$ for 4 hours. The sample was taken out from the previous step to a dryer and cool to room temperature, then recorded the weight of the sample and add acidic washing solution for 60 min, take out the filter bag and rinse with acetone for $5 \mathrm{~min}$, dry naturally. The filter bag was put into the oven at $100{ }^{\circ} \mathrm{C}$ for 4 hours, then cooled to room temperature in a dryer and weigh it. The filter bag was immersed in $72 \%$ sulfuric acid solution for 3 hours, rinse the filter bag to $\mathrm{pH}$ neutral with water, then rinse with acetone for $3 \mathrm{~min}$, dry naturally. The filter bag was put in a $100^{\circ} \mathrm{C}$ oven for 4 hours, dry and weighed it after cooling to room temperature.

The root system was measured by scanning method ${ }^{[40]}$ at the end of harvest (November 10, 2015 for AC and on May 30, 2016 for SC). The whole root system of a celery was collected and rinsed with water, in three replications, then scanned the root system in the EPSOM EXPRESSION 4990 (Seiko Epson Corporation, ChangYe, Germany). The data of root length (RL), root surface area (RSA), root volume (RV) were analyzed by WinRHIZO (Regent Instrument Inc, Ville de Québec, QC Canada).

\section{Calculation of WUE}

Economic and biological of WUE (WUE $\mathrm{e}_{\mathrm{e}}$ and $\mathrm{WUE}_{\mathrm{b}}$, respectively) were calculated with the following formulas:

$\mathrm{WUE}_{\mathrm{e}}=\mathrm{EY} / \mathrm{I},(2)$

$\mathrm{WUE}_{\mathrm{b}}=\mathrm{BY} / \mathrm{I},(3)$

where EY is the economic yield $(\mathrm{kg})$, including the fresh weight of the stems and leaves in celery, BY is the biological yield $(\mathrm{kg})$, including the fresh weight of the roots, stems, and leaves in celery, and I is the irrigation content $\left(\mathrm{m}^{3}\right)$.

\section{Data analysis}

The data were analyzed by Excel and SPSS 13.0, and data from each sampling event were analyzed separately. The data were subjected to analysis of variance (ANOVA) and Duncan's least significant 
difference (LSD) test to determine the significance, and the significance was set as $p<0.05$. The homogeneity of variances was checked by Bartlett tests, and the normality of the variables was tested by the Shapiro-Wilk test.

\section{Abbreviations}

FI: Furrow irrigation; MS: Micro-sprinkler irrigation; PF: Furrow irrigation under plastic film mulching; MSP: Micro-sprinkler irrigation under the plastic film mulching; AC: Autumn season crop; SC: Spring season crop; WUE $E_{\mathrm{e}}$ : Economic of WUE; WUE : biological of WUE; RL: root length; RSA: root surface area; RV: Root volume.

\section{Declarations}

\section{Ethics approval and consent to participate}

Not applicable.

\section{Consent for publication}

Not applicable.

\section{Availability of data and materials}

All data were generated or analyzed during this study are included in this published article and its additional files.

\section{Competing interests}

The authors declare that they have no conflict of interest.

\section{Funding}

This study was supported by Beijing Leafy Vegetables Innovation Team of Modern Agro-industry Technology Research System (BAIC07-2020) and The Construction of Beijing Science and Technology Innovation and Service Capacity in Top Subjects (CEFF-PXM2019_014207_000032). The funding bodies were not involved in the design of the study, collection, analysis, and interpretation of data, and in writing the manuscript.

\section{Authors' contributions}

WSL, WQ and JXT conceived and designed research. WSL, LC and JXT conducted experiments and analyzed data. WSL and XY configured the structure of the manuscript. WSL wrote the manuscript. WSL, LC, $X Y$ and WYX revised the paper. All authors have read and approved the manuscript. 
Acknowledgements

We acknowledge all the members of the research team for their assistance in the work

\section{Author details}

1 Department of Vegetable Sciences, Beijing Key Laboratory of Growth and Developmental Regulation for Protected Vegetable Crops, China Agricultural University, Beijing, China.

\section{References}

1. Sun Q, Zhao H, Zhang GD, Zhang YP, Zhang L, Liu GH. Present status,problems and measures of facility horticulture in southern mountain area of ningxia. Journal of Agricultural Sciences. 2011;32(2):77-81.

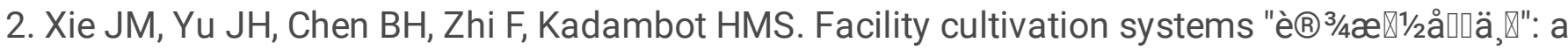
chinese model for the planet. Adv Agron. 2017;145:1-42.

3. Dalvi VB, Tiwari KN, Pawade MN, Phirke PS. Response surface analysis of tomato production under microirrigation. Agric Water Manag. 1999;41(1):0-19.

4. Prabhat S, Chauhan HS. Comparative performance of cabbage Brassica oleracea var. capitata under different irrigation methods. Journal of Applied Horticulture. 1999;1(2):137-8.

5. Piri H, Naserin A. Effect of different levels of water, applied nitrogen and irrigation methods on yield, yield components and IWUE of onion. Scientia Horticulturae. 2020; 268,109361.

6. Oktem A. Effect of water shortage on yield, and protein and mineral compositions of drip-irrigated sweet corn in sustainable agricultural systems. Agric Water Manag. 2008;95(9):0-1010.

7. Fabeiro C, Olalla FMDS, Juan JAD. Production of muskmelon (Cucumis melo L.) under controlled deficit irrigation in a semi-arid climate. Agric Water Manag. 2002;54(2):0-105.

8. Erdem Y, Yuksel AN. Yield response of watermelon to irrigation shortage. Scientica Horticulture. 2003;98:365-83.

9. Li Q, Li HB, Zhang L, Zhang SQ, Chen YL. Mulching improves yield and water-use efficiency of potato cropping in china: a meta-analysis. Field Crops Research. 2018;221:50-60.

10. Juan C, Díaz-Pérez. Root zone temperature, plant growth and yield of broccoli [brassica oleracea (plenck) var. italica] as affected by plastic film mulches. Sci Hortic. 2009;123(2):0-163.

11. Mireia NZ, Larregla S, Garbisu C. Application of organic amendments followed by soil plastic mulching reduces the incidence of Phytophthora capsici in pepper crops under temperate climate. Crop Prot. 2011;30(12):1563-72.

12. Stapleton JJ, Devay JE. Soil solarization: a non-chemical approach for management of plant pathogens and pests. Crop Prot. 1986;5(3):190-8.

13. Li CJ, Wang CJ, Wen XJ, Qin XL, Liu Y, Han J. Ridge-furrow with plastic film mulching practice improves maize productivity and resource use efficiency under the wheat-maize double-cropping 
system in dry semi-humid areas. Field Crops Research. 2017;203:201-11.

14. Dong QG, Yang YC, Yu K, Feng H. Effects of straw mulching and plastic film mulching on improving soil organic carbon and nitrogen fractions, crop yield and water use efficiency in the Loess Plateau, China. Agricultural Water Management. 2018;201:133-43.

15. Chen ZJ, Han YY, Ning K, Luo C, Sheng W, Wang SL, Fan SX, Wang YF, Wang Q. Assessing the performance of different irrigation systems on lettuce (Lactuca sativa L.) in the greenhouse. Plos One. 2019;14(2).

16. Zhao H, Wang RY, Ma BL, Xiong YC, Qiang SC, Wang CL. Ridge-furrow with full plastic film mulching improves water use efficiency and tuber yields of potato in a semiarid rainfed ecosystem. Field Crops Research. 2014;161:137-48.

17. Kirnak H, Demirtas MN. Effects of different irrigation regimes and mulches on yield and macronutrition levels of drip-irrigated cucumber under open field conditions. J Plant Nutr. 2006;29(9):1675-90.

18. Sun YM, Wang M, Li YR, Gu ZH, Ling N, Shen QR, Guo SW. Wilted cucumber plants infected by Fusarium oxysporum f. sp. cucumerinum do not suffer from water shortage. Ann Bot. 2017;120(3):427-36.

19. Gallardo M, Thompson RB, Valdez LC, Fernández MD. Response of stem diameter variations to water stress in greenhouse-grown vegetable crops. Journal of Horticultural Science Biotechnology. 2006;81(3):483-95.

20. Rameshwaran P, Tepe A, Yazar A, Ragab R. Effects of drip-irrigation regimes with saline water on pepper productivity and soil salinity under greenhouse conditions. Sci Hortic. 2016;199:114-23.

21. Tornblom O, Lindgren B, Johansson AV. Irrigation water management of horticultural crops. Hortscience. 2003;38(5):1036-42.

22. Sezen SM, Yazar A, Tekin S. Physiological response of red pepper to different irrigation regimes under drip irrigation in the Mediterranean region of Turkey. Sci Hortic. 2019;245:280-8.

23. Drost D. West, Brandon. Celery in the garden. Garden. 2006;3.

24. Liu CP, Luo CL, Xu XH, Wu CA, Li FB, Zhang G. Effects of calcium peroxide on arsenic uptake by celery (Apium graveolens L.) grown in arsenic contaminated soil. Chemosphere. 2012;86(11):110611.

25. Zavadil J. Optimisation of irrigation regime for early potatoes, late cauliflower, early cabbage and celery. Soil Water Research. 2006;1(No. 4):139-52.

26. Ramalan AA, Nega H, Oyebode MA. (2010). Effect of deficit irrigation and mulch on water use and yield of drip irrigated onions. Sustainable Irrigation Management, Technologies and Policies III. 2010;134:39-49.

27. Zhang F, Zhang WJ, Qi JG, Li FM. A regional evaluation of plastic film mulching for improving crop yields on the loess plateau of china. Agric For Meteorol. 2018;248(5):458-68. 
28. Xue NW, Xue JF, Yang ZP, Sun M, Ren AX, Gao ZQ. Effects of film mulching regime on soil water status and grain yield of rain-fed winter wheat on the Loess Plateau of China. Journal of Integrative Agriculture. 2017;16(11):2612-22.

29. Leonardi C, Guichard S, Bertin N. High vapour pressure deficit influences growth, transpiration and quality of tomato fruits. Sci Hortic. 2000;84(3-4):0-296.

30. Yin W, Hen GP, Feng FX, Guo Y, Hu FL, Chen GD, Zhao C, Yu AZ, Chai Q. Straw retention combined with plastic mulching improves compensation of intercropped maize in arid environment. Field Crops Research. 2017;204:42-51.

31. Zhao H, Wang RY, Ma BL, Xiong YC, Qiang SC, Wang CL, LI MF. Ridge-furrow with full plastic film mulching improves water use efficiency and tuber yields of potato in a semiarid rainfed ecosystem. Field Crops Research. 2014;161:137-48.

32. Li R, Hou XQ, Jia ZK, Han QF. Mulching materials improve soil properties and maize growth in the northwestern loess plateau, china. Soil Research. 2016;54(6):708.

33. Jaime KM, John MD, Janet CC. Influence of irrigation system and frequency on plant growth, root distribution, and water-use efficiency. Hortscience. 1995;4:798.

34. Warman PR, Termeer WC. Evaluation of sewage sludge, septic waste and sludge compost applications to corn and forage: yields and N, P and K content of crops and soils. Biores Technol. 2005;96(8):955-61.

35. Mbarki S, Labidi N, Mahmoudi H, Jedidi N, Abdelly C. Contrasting effects of municipal compost on alfalfa growth in clay and in sandy soils: N, P, K, content and heavy metal toxicity. Biores Technol. 2008;99(15):6745-50.

36. Zhang CQ, Chen RH, Feng XH, Cheng XQ, Zhang GP, Fan ZL. Investigation on species and distribution of weeds in tobacco fields in Jiangxi province. Acta Agriculturae Jiangxi. 2012;85:80-2.

37. Liu H, Fu YM, Hu DW, Yu J, Liu H. Effect of green, yellow and purple radiation on biomass, photosynthesis, morphology and soluble sugar content of leafy lettuce via spectral wavebands "knock out". Sci Hortic. 2018;236:10-7.

38. Moor U, Karp K, Priit P, Pae A. Cultural systems affect content of anthocyanins and vitamin $c$ in strawberry fruits. European Journal of Horticultural Science. 2005;70(4):195-201.

39. Evers AM, Ketoja E, Hagg M, Plaami S, Hakkinen U, Pessala R. Decreased nitrogen rates and irrigation effect on celery yield and internal quality. Plant Foods Hum Nutr. 1997;51(3):173-86.

40. Zhang ZY, Wang XJ, Guo SL. Influences of image resolution on herbaceous root morphological parameters. Journal of Shanghai Normal University. 2014;43(3).

\section{Figures}




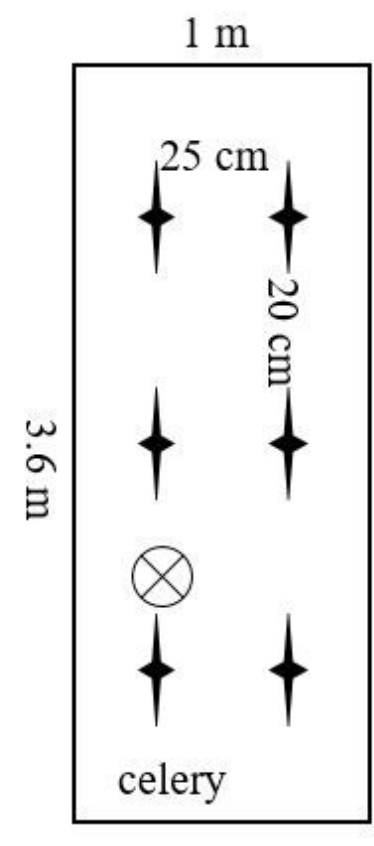

(a)

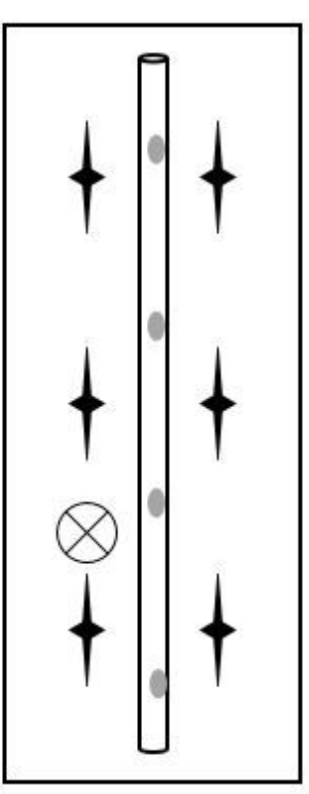

(b)

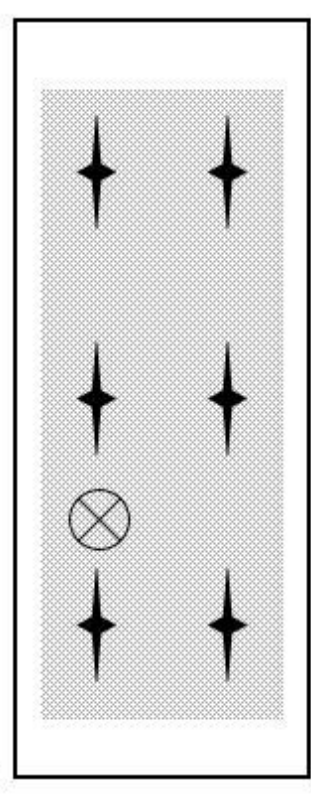

(c)

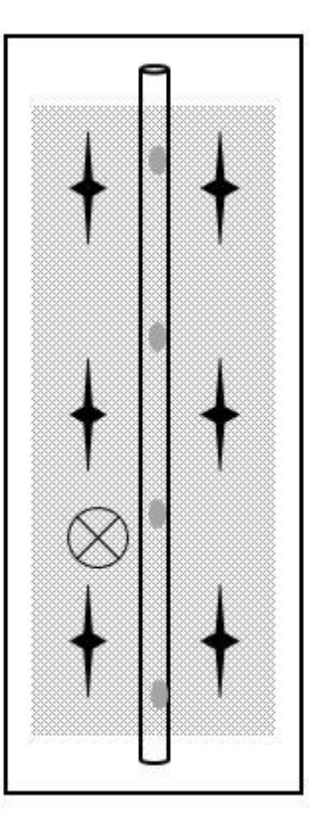

(d) diameter $28.6 \mathrm{~mm}$

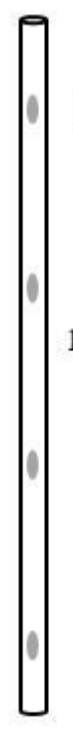

hole diameter $0.1 \mathrm{~mm}$

micro-sprinkler pipes

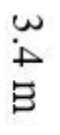

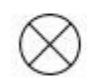

moisture transducer

(e)

(f)

\section{Figure 1}

Planting of the four irrigation techniques: (a) furrow irrigation ( $\mathrm{Fl}),(\mathrm{b})$ micro-sprinkler irrigation (MS), (c) furrow irrigation under plastic film mulching (PF), (d) micro-sprinkler irrigation under the plastic film mulching (MSP), (c) and (d) gray shades are black agricultural plastic film with a thickness of $0.01 \mathrm{~mm}$, (e) micro-sprinkler pipes with a diameter of $28.6 \mathrm{~mm}$ and an $0.1 \mathrm{~mm}$ diameter hole, (f) moisture transducer (Shengshixintong Technology, Beijing, China): used moisture transducer monitoring soil moisture. 


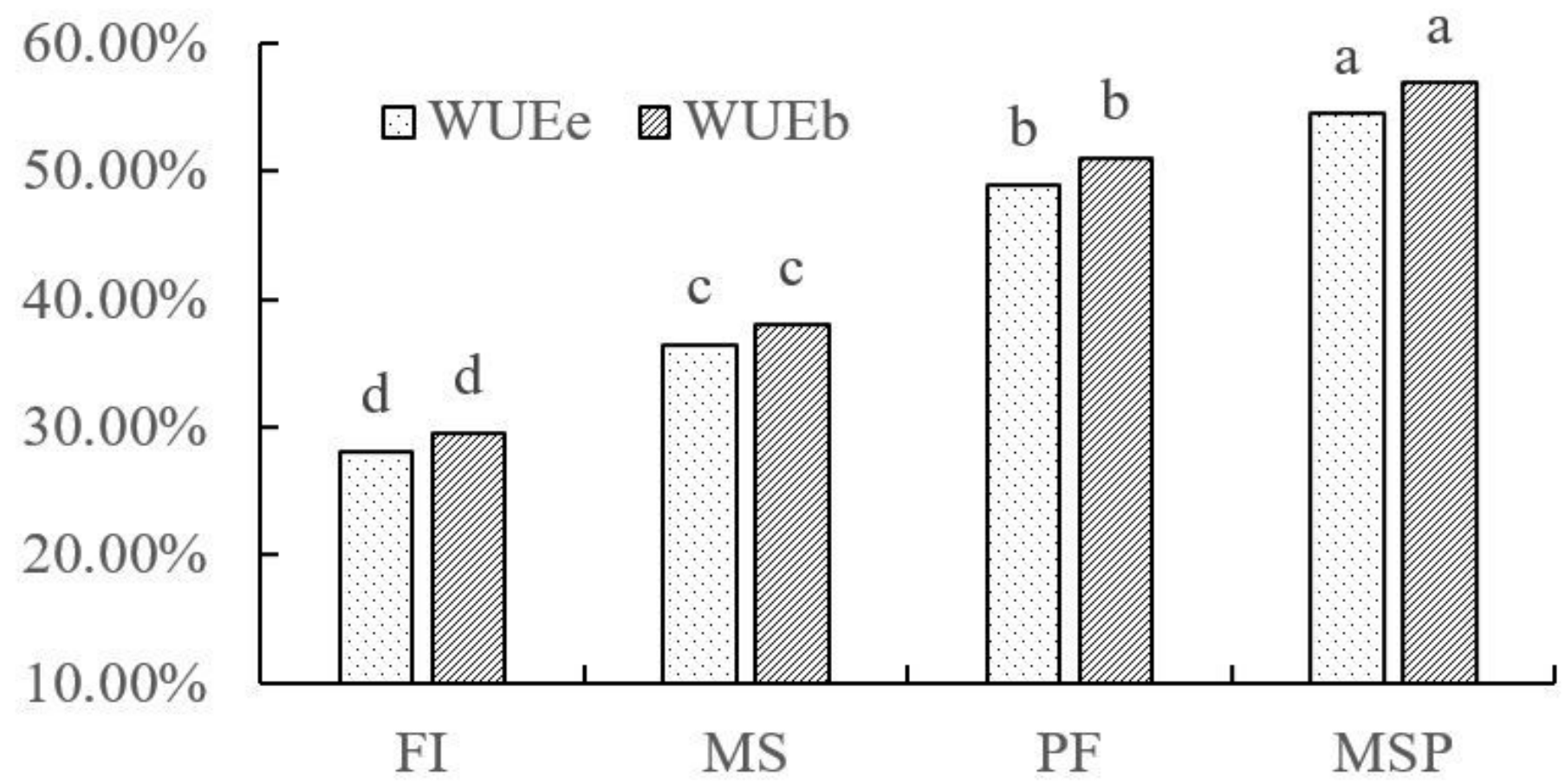

Figure 2

Effects of water irrigation techniques on WUE in AC: WUEe is WUE of economic yield and WUEb is WUE of biological yield. Values are means $(n=3)$, different lower case letters $(a, b, c, d)$ indicate the significant differences at $p<0.05$ according to Duncan's least signifificant difference (LSD) test.

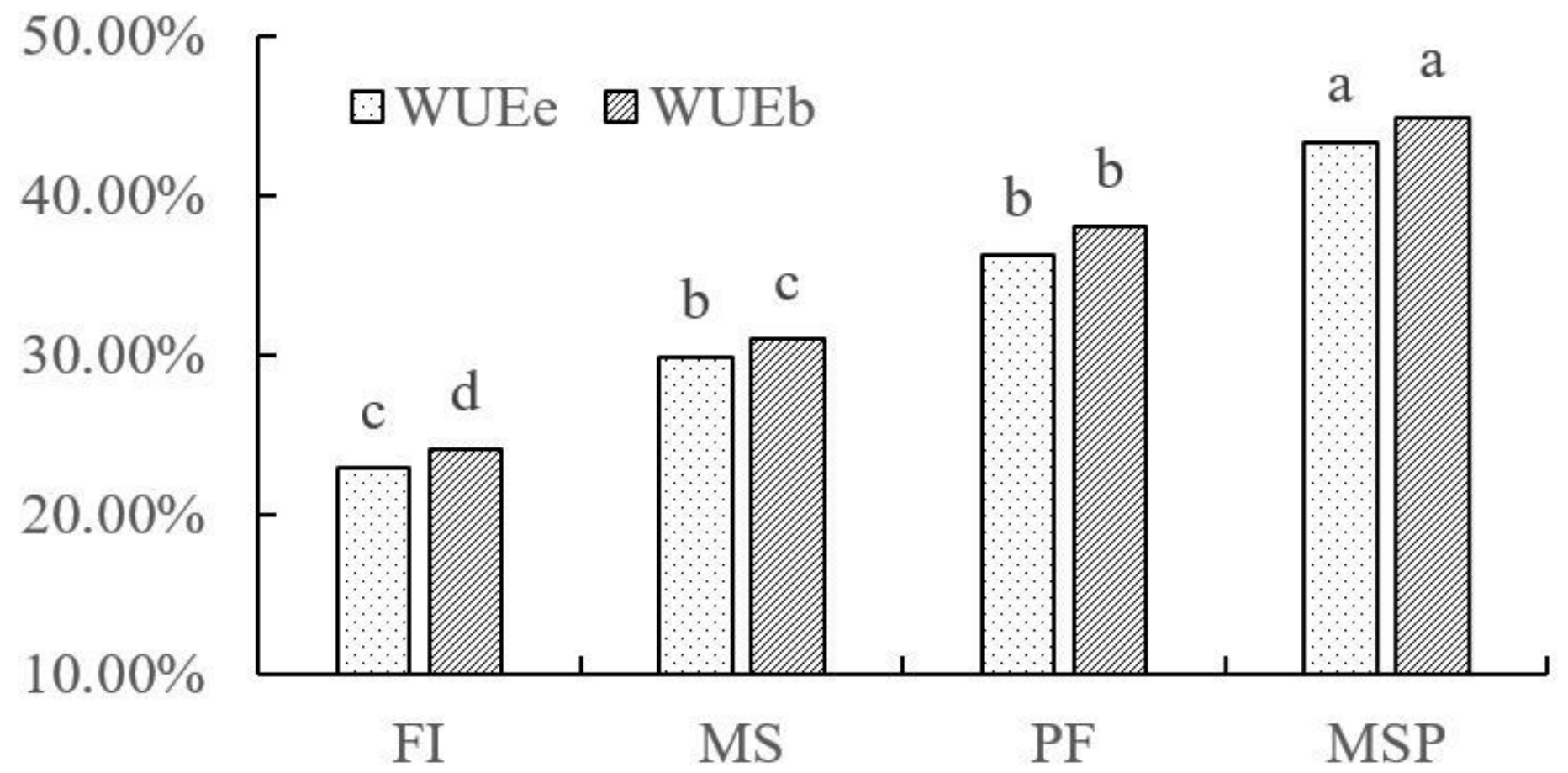


Figure 3

Effects of water irrigation techniques on WUE in SC: WUEe is WUE of economic yield and WUEb is WUE of biological yield. Values are means $(n=3)$, different lower case letters $(a, b, c, d)$ indicate the significant differences at $p<0.05$ according to Duncan's least signifificant difference (LSD) test.
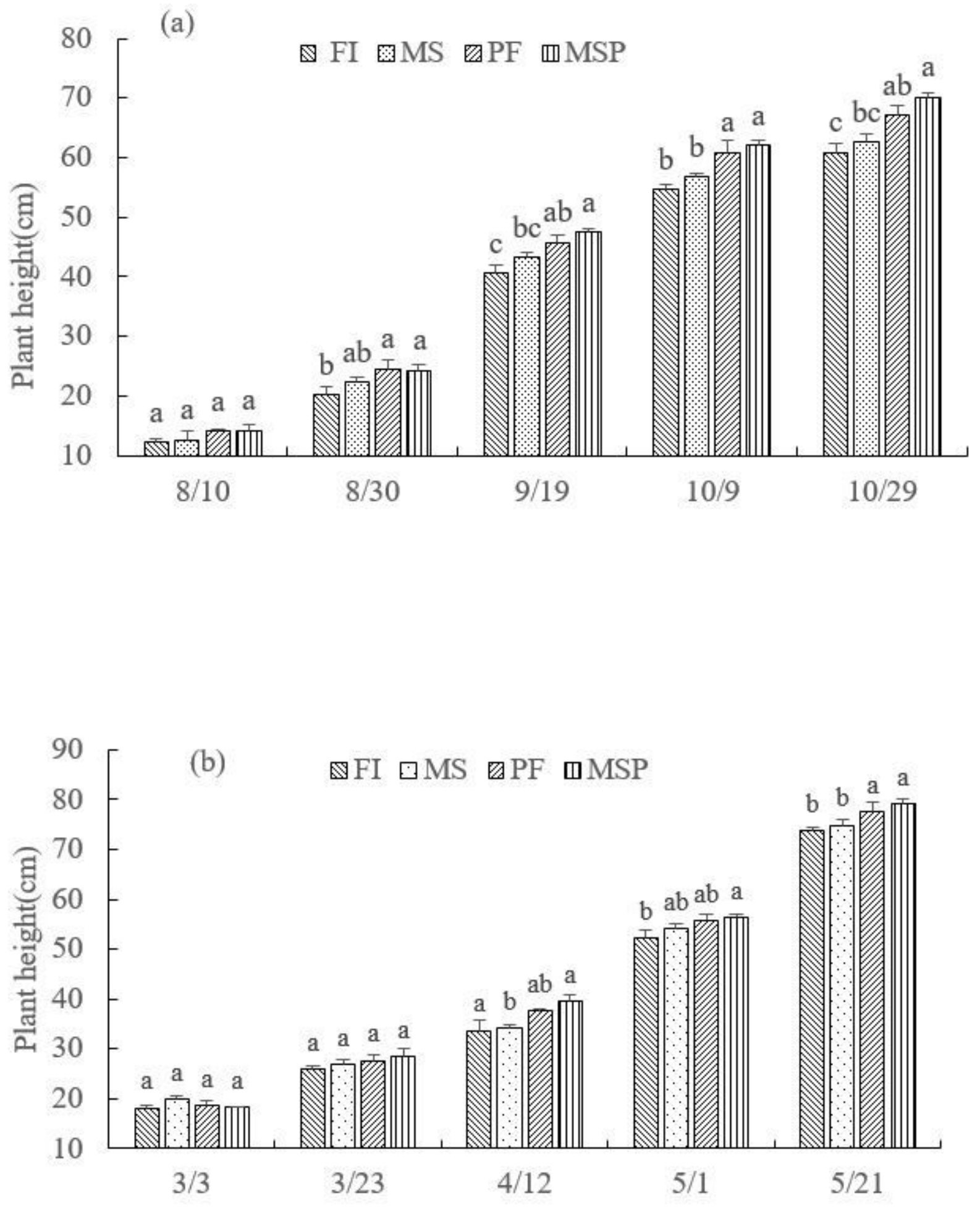

Figure 4 
Effects of different irrigation techniques on plant height: AC (a), SC (b). Values are means \pm standard deviation $(n=3)$, different lower case letters $(a, b, c)$ indicate the significant differences at $p<0.05$ according to Duncan's least signifificant difference (LSD) test.

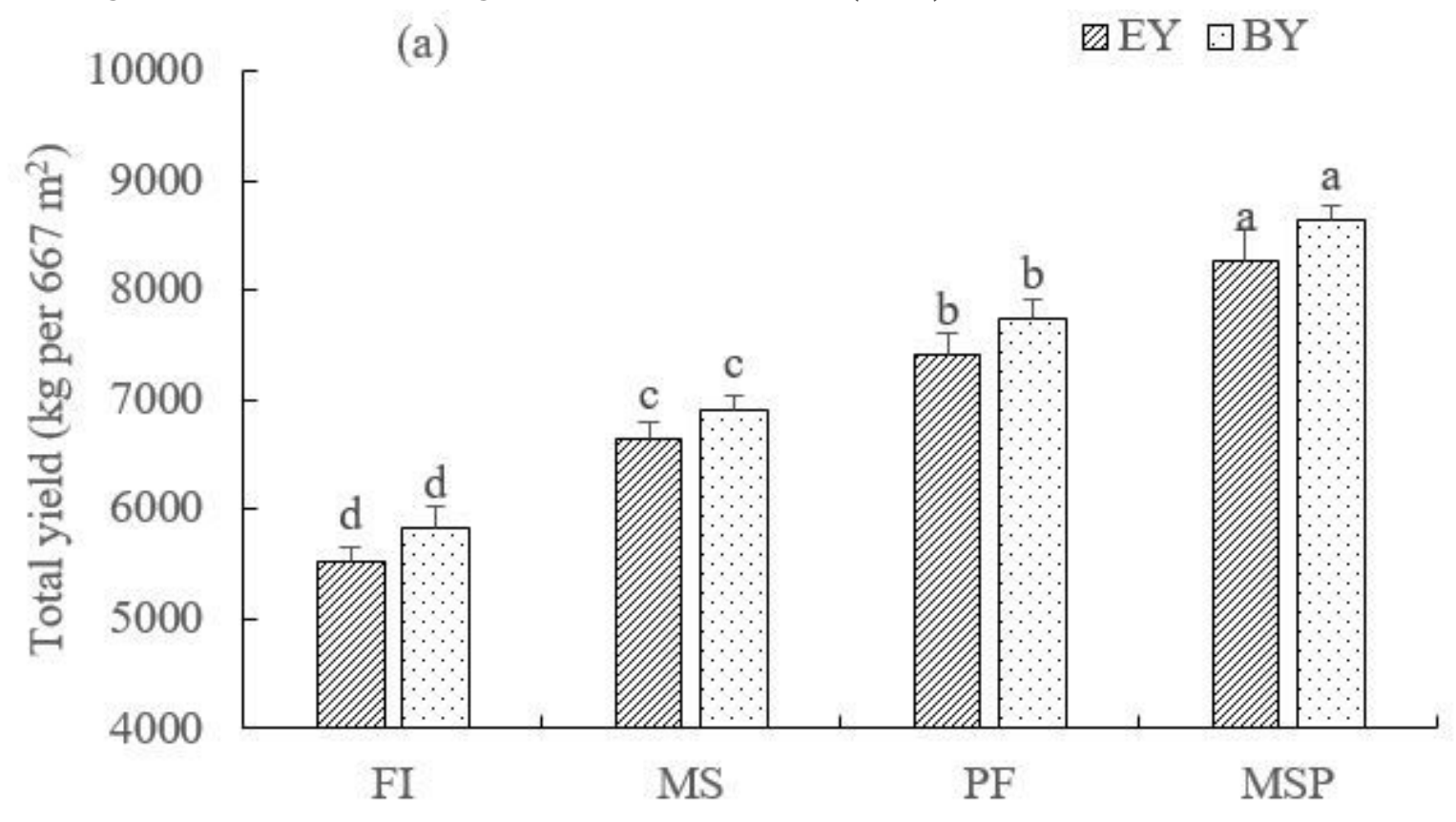

(b)

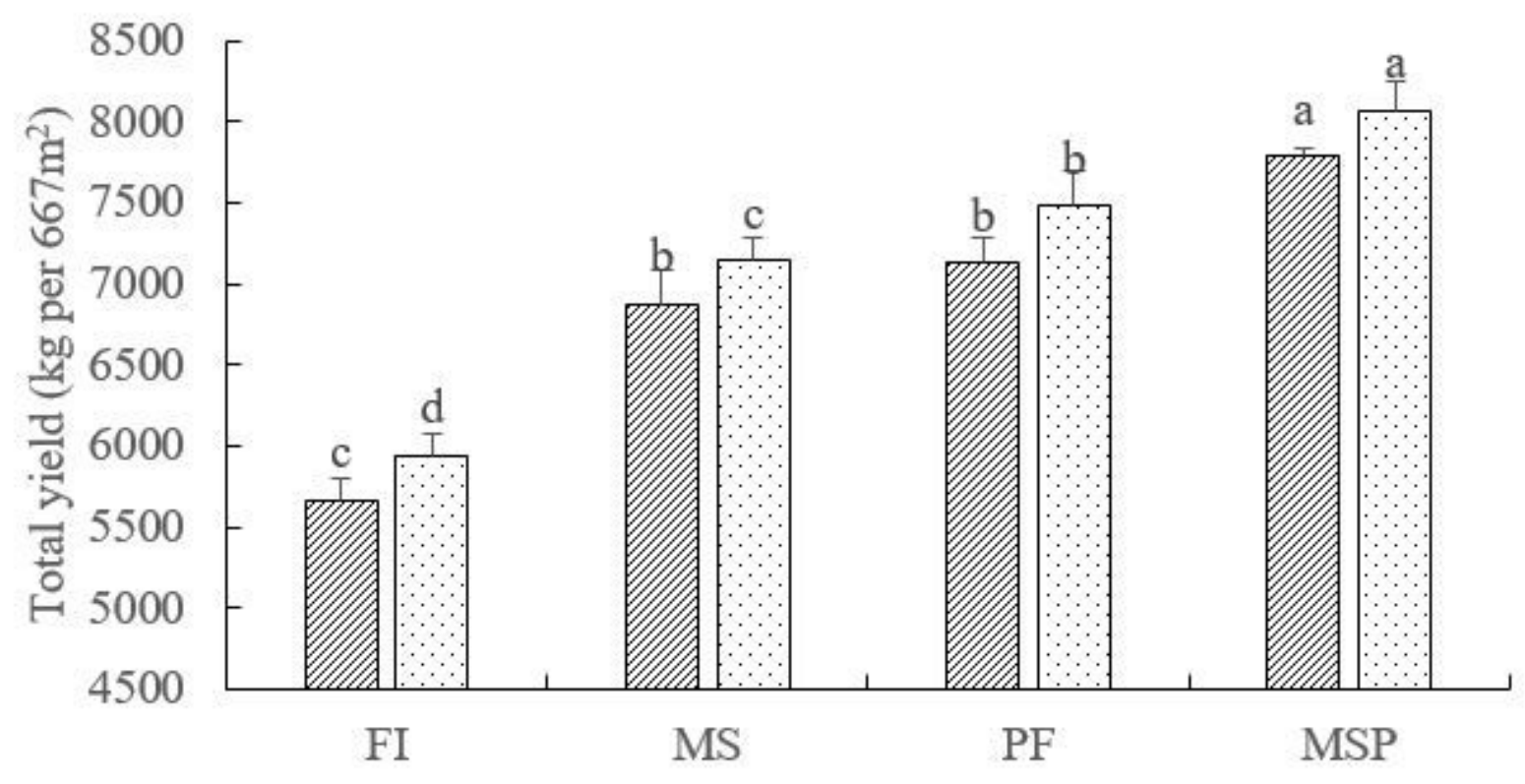

Figure 5

Effects of different irrigation techniques on total yield of celery: AC (a), SC (b), EY is the economic yield $(\mathrm{kg}), \mathrm{BY}$ is the biological yield $(\mathrm{kg})$. Values are means \pm standard deviation $(\mathrm{n}=3)$, different lower case 
letters $(a, b, c, d)$ indicate the significant differences at $p<0.05$ according to Duncan's least signifificant difference (LSD) test. 